\title{
The purpose of the complex treatment for patients with posttraumatic lesions at the hand level
}

\author{
${ }^{1}$ Sînziana Călina Silișteanu, ${ }^{2}$ Andrei Dănuț Haidamac \\ ${ }^{1}$ Railway Hospital Iasi - Specialty Ambulatory - "Stefan cel Mare" University of Suceava \\ 2Student - FEFS-DSDU "Stefan cel Mare" University of Suceava \\ sinzi_silisteanu@yahoo.com
}

\begin{abstract}
Introduction. The tendons at the hand level are thin and long in comparison to the ones in the other parts of the body, which allows them to slide on long distances and to make the flexion/extension movements just like in a pulley. The evolution and the prognosis of the lesions in the flexor/extensor tendons depend on the location of the lesion, on the age of the patient, the presence of comorbidities and the occurrence of complications. The combination between the kinetic therapeutic recovery techniques and the physical therapeutic recovery techniques led to the improvement of the pain and of the functionality of the sick structures as well as an increase in the quality of life, by providing faster integration for patients in the social economic activity. Material and methods - This work has had the purpose of proving that the use of a complex rehabilitation treatment can intervene in reducing the length of the treatment for patients with postraumatic hand lesions. The aimed objectives were to reduce the pain and the inflammation, to increase mobility at the level of the joints and implicitly to increase the force and the stability for this segment, to prevent stiffness and retractions from settling in, but also to improve the quality of patients' lives. Conclusions - According to the obtained results, it is possible to consider that: the patients who took part in this trial made progress regardless of the stage from which the recovery started but also regardless of the patients' gender and age, the used treatment must be individualized and used progressively and there are no significant modifications according to the location of the lesions of the flexor tendons and of the extensor tendons.
\end{abstract}

Key words: pain, functional independence, the reduction of mobility, rehabilitation

\section{Introduction}

This complex has a vast structure represented by bones, muscles, ligaments, tendons, joints, vessels and nerves among which there is no free space; this is the reason why the isolated traumatic lesions seldom occur [1]. The traumas at the hand level may be classified into: tendon lesions, paralysis of the peripheral nerves, amputations and stiff hand [2].

The encountered tendon lesions may be open since they frequently occur after a fracture or after touching a sharp object; they may also be closed since the tendons rub against a bony plane or within chronic diseases such as the rheumatoid polyarthritis [3].

The most frequent lesions are the ones of the flexor tendons when the functionality of the hand gets lost, especially in the area of the carpal tunnel, of the metacarpal bones in the area of the carpal tunnel and of the proximal and distal phalanxes

[4]. 
The most important lesions are at the following levels:

- at the cubital level, where it is impossible to make the flexion of the distal phalanx for the fourth and fifth fingers,

- at the radial level, where it is impossible to make the extension of the fingers at the level of the metacarpophalangeals;

-at the median level, with the flexion / pronation deficit for the wrist and with the flexion deficit for the thumb/middle finger [2]

In the lesions of the flexor/extensor tendons of the hand, the symptoms are the pain, the local tumefaction, the presence of muscular retraction/atrophies and the stiffness of the joints with the functional impairment. [5]

The causes that may produce this type of lesions may be mechanical (strokes, traumas by sharp objects), physical (frostbites, burns), chemical (corrosions) or biological (stings, bites).

At the level of the hand, according to the movements that can be made, the muscles may be classified in the following way:

- The muscles that control the flexion movement: the radial flexor muscle of the carp, the long palmar muscle, the ulnar radial muscle of the carp and the flexor muscles of the fingers

- The muscles that control extension: the ulnar extensor muscle of the carp, the long radial extensor muscle and the short radial extensor muscle of the carp
- The muscles that control abduction: the ulnar flexor muscle of the carp, the ulnar extensor of the carp

- The muscles that control abduction: the long radial extensor muscle and the short radial extensor muscle of the carp, the long abductor muscle, the short extensor muscle and the long extensor muscle of the thumb [6]

At the level of the metacarpophalangeal joints, we have to mention the dorsal interbony muscles (the flexion of the proximal phalanx, the extension of the second and third phalanxes, and the abduction of the fingers), the palmar interbony muscles (the flexion of the proximal phalanx, the extension of the second and third phalanxes, and the abduction of the fingers), the common extensor muscle of the fingers (the extension of the hand phalanges and of the hand, the abduction of the hand and of the fingers), the extensor muscle of the little finger (the extension of the hand and of the little finger), the extensor muscle of the forefinger (the extension of the hand and of the index finger).

The following movements are made at the thumb level: flexion (the long flexor muscle and the short flexor muscle of the thumb), extension (the long extensor muscle and the short extensor muscle of the thumb), abduction (the long abductor muscle of the thumb, the short extensor muscle of the thumb, the short abductor muscle of the thumb), abduction (the long extensor muscle of the thumb, the abductor of the thumb) and the opposition (the opposing thumb) [7, 8]. 
The possibility to make the grip at this level is very important. Thus, the hand and the fingers can make together the terminal, subterminal, subterminal lateral, palmar, digital palmar and lateral grip.

The evolution and the prognosis of the flexor/extensor tendon lesions depend upon the location of the lesion, the patient's age, the presence of comorbidities and the occurrence of complications.

After a traumatic lesion, some situations require a surgical treatment [9] that will have to be completed by recovery procedures, namely: electrical therapy (of low and average frequency), thermal water therapy, massage and kinetic therapy. As for the surgical repairs of the tendons, it is considered that the extensor tendons can be fixed more easily in comparison to the flexor tendons whereas the therapeutic attitude is different according to the location of the lesion $[3,5,10]$.

The treatment by medication has the purpose of reducing pain and tumefaction, being represented by anti-inflammatory and antialgic medication.

The kinetic therapy within the recovery treatment has the following objectives:

-to reduce pain and oedema

- to keep mobility at the level of the joints

-to fight against vicious attitudes and postsurgical complications

-to keep the force and the stability of the hand

-to keep and to improve the ability at the level of the hand

- to recover the grip
The dynamic-type ortheses will be useful, too if they are worn in order to prevent the deformation and to keep the mobility gained after the kinetic therapy sessions [5].

The recovery treatment can start 4 or 5 weeks after the surgical intervention, first by passive mobilization exercises, then by active mobilization for the joints of the fingers and for the wrists. It is possible in the sixth week to do endurance exercises by means of progressive application by the kinetic therapist but also proprioceptive facilitation techniques aimed at accelerating the voluntary motor response at the level of the muscle, of the tendons and of the joints [11]. The final objective is the recovery of the force and of the endurance at the level of the hand, which should allow the movements to be made at normal amplitude. When the recovery programme is used properly, it is possible to avoid the occurrence of complications represented especially by the development of tendinous adherences that may block the movement. $[5,10,12]$.

The electrical therapy is used for an antialgic, anti-inflammatory and anti-trophic purpose for tissues [13]. The following ones are used: the galvanic power (with an antiinflammatory and analgetic effect), the low frequency power - the diadynamic power (with an anti-inflammatory effect), the average frequency power - the interferential power (with an analgetic vascular-trophic effect), the laser (with an analgetic and vascular-trophic effect), the ultrasounds (with a fibrolitic effect), the electimulation (with a relaxation effect of the spastic musculature) [13].

The massage has a vasodilator and decontracting role; it will be made before 
the kinetic therapy exercises and it has as effects the local hyperemia, the favouring of the tissue trophicity, the eliminare of certain liquids, the decrease of the intramuscular pressure by improving the algic symptomatology [14, 15].

Thus, the following movements can be made: levelling (in order to activate the blood circulation and to decrease the pain), friction (in order to mobilize the subjacent structures, to increase the elasticity and the suppleness of tissues), shaking, rolling and sieving (in order to increase the suppleness of tissues and to develop the excitability of muscles), tensions and tractions (in order to stretch the articulary and periarticulary elements), pinching (in order to stimulate and to revigorate) $[14,15,16]$.

Another recovery method is the thermal water therapy that may include: criotherapy (for the vasoconstrictor and analgesic purpose), the wrapping with paraffin or mud (for the trophic hyperemiant antialgic purpose), cold compresses of Priessnitz-type (for the antalgic and sedative purpose), baths with medicinal plants (for the ressorbtive antalgic purpose) and the shower massage (with a ressorbtive effect) $[17,18]$.

Bath therapy is also recommended to patients with traumas at the level of the hand tendons, by using natural therapeutic factors that have a beneficial role in the improvement of the health condition. Thus, these patients can benefit from bath therapy in Mangalia, Eforie Nord, Techirghiol, Amara, Lacu Sărat (chlorinated natrium waters and sapropelic mud), Târgu Ocna (mineral chlorinated natrium waters), Slănic Moldova (mineral, sulphurous, chlorinated natrium oligomineral waters), Olăneşti (chlorinated natrium iodine sulphurous waters) [19].

The purpose of the occupational therapy is to recover the ability of the hand and to help the patient do the daily activities, be reintegrated in the professional activities and to use objects according to the functional remainder [20].

The ability of the hand can be re-gained by a series of activities such as: cleaning windows, pot making, shaping the dough, packing/wrapping objects, writing, sewing, gardening, adding beads on a piece of string or inserting light bulbs. Moreover, the games are useful for recovery: darts, chess and checkers, by contributing to the reintegration of the hand into the kinetic chain of the upper limb and to the mobilization of both hands.

\section{Material and method}

This work has had the purpose of proving that the use of a complex rehabilitation treatment can intervene in reducing the length of the treatment for patients with postraumatic hand lesions.

The aimed objectives were to reduce the pain and the inflammation, to increase mobility at the level of the joints and implicitly to increase the force and the stability for this segment, to prevent stiffness and retractions from settling in, but also to improve the quality of patients' lives.

The current trial included twenty-six patients among which twelve male patients and fourteen female patients who had posttraumatic hand lesions at the level of the flexor tendons and extensor tendons. These patients were under medical investigations for three months. The trial was performed in the ambulatory whereas the patients 
underwent a recovery treatment for twenty days; the evaluation was made at the beginning and at the end of the treatment whereas the medical check-up was made six weeks later.

The patients of this trial were informed about the recovery treatment they would benefit from and they signed the consent application form, knowing that their personal data were confidential.

The patients answered some questionnaires, namely: the pain evaluation scale (VAS), the functional independence balancesheet (BIF) used for the evaluation of the performance deficit of the ADLs, the quantified evaluation scale of the quality of life (QOL).

All the patients underwent an articulary balancesheet (at the level of the radiocarpal, metacarpophalangeal and interphalangeal joints) as well as a muscular balancesheet in the gravity position and in the non gravity position.

The programme used by patients was structured and applied on stages. The first stage aimed at reducing the pain, the oedema and the retractions as well as to re-gain the movement amplitude; the second stage aimed at increasing the articulary amplitude, the muscular force and the articulary stability; the third stage aimed at improving the ability for this segment by re-educating the prehension and by re-gaining the independence of the patients' movements.

The kinetic therapy sessions were preceded by massage sessions and included passive mobilizations in flexion and in extension. Then ortheses were used in order to restrict the extension and the flexion at the level of the wrist, of the metacarpophalangeal joints, of the proximal and distal interphalangeal joints (for the lesions of the flexor tendons) and extension splints that were used at the level of the metacarpophalangeal joints, of the proximal and distal interphalangeal joints (for the lesions of the extensor tendons).

In the second stage of kinetic therapy, there were active mobilizations performed at the level of the hand and of the fingers, opposition movements of the thumb with the other fingers as well as tractions in the longitudinal axis.

In the last stage there were exercises with endurance use and neuroproprioceptive facilitation techniques.

\section{Results}

The statistical data aimed at the average, the median and the standard deviation for the obtained values after using the scales before the treatment, after it but also during the medical check-up whereas the t-student test was used for all the three moments.

Thus, the obtained data for the trial group can be seen in Table 1 and in Graph 1.

Table 1 . The statistic processing of the data for the trial group

\begin{tabular}{|c|c|c|c|}
\hline Moment/Scala & VAPS & BFI & QOL \\
\hline Initial & $8 \pm 0.77$ & $29 \pm 3.59$ & $0.24 \pm 0.07$ \\
\hline Final & $5 \pm 0.56$ & $23 \pm 3.84$ & $0.54 \pm 0.03$ \\
\hline Control & $3 \pm 0.41$ & $16.5 \pm 3.33$ & $0.91 \pm 0.09$ \\
\hline
\end{tabular}

The table above shows, for the standard deviation and for the median, the reduction of the pain level from 8 to 3 , the reduction of the values for the functional independence from 29 to 16.5 as well as the improvement of the life quality from 0.24 to 0.91 . 


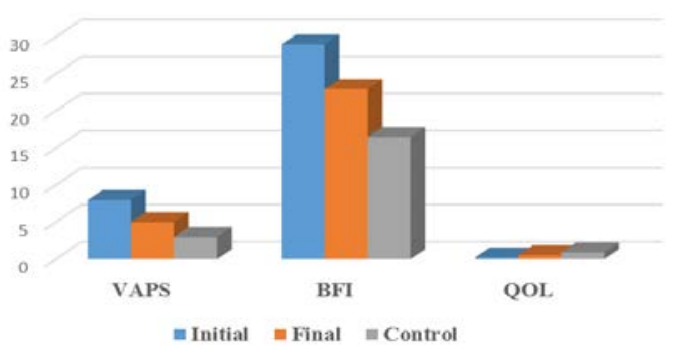

Graph no. 1. The values of the median for the trial group

Table 2 and Graph 2 present the obtained data for BIF scale with the main segments food/hygiene, dressed in the upper and lower parts of the body but also for the communication/interaction elements with the social environment (writing, driving, using the keys of the phone/card, using the door key/car key, opening doors/ windows, laying the table).

Table 2. The statistical processing of the data for the trial group - BIF scale segments

\begin{tabular}{|l|l|l|l|}
\hline $\begin{array}{l}\text { Moment/ } \\
\text { Scala }\end{array}$ & $\begin{array}{l}\text { Food / } \\
\text { Hygiene }\end{array}$ & $\begin{array}{l}\text { Dressed } / \\
\text { undressed }\end{array}$ & $\begin{array}{l}\text { Interaction with the } \\
\text { social environment }\end{array}$ \\
\hline Initial & $9 \pm 1.52$ & $8 \pm 2.57$ & $12 \pm 2.57$ \\
\hline Final & $7 \pm 1.38$ & $6 \pm 2.58$ & $9 \pm 1.63$ \\
\hline Control & $5 \pm 1.26$ & $4 \pm 2.14$ & $6 \pm 1.49$ \\
\hline
\end{tabular}

For BIF scale, for each of the component segments, there are now values of the median and of the standard deviation that are showing the good evolution of the patients after using a complex recovery treatment.

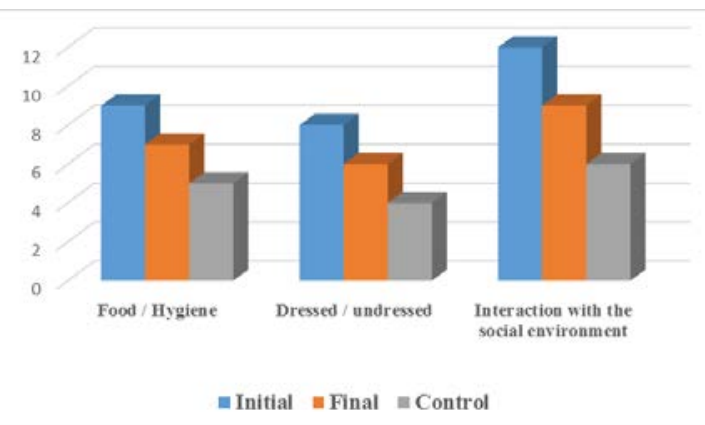

Graph no. 2. The values of the median for the trial group - BIF scale segments

\section{Conclusions}

According to the obtained results, it is possible to consider that:

- the patients who took part in this trial made progress regardless of the stage from which the recovery started but also regardless of the patients' gender and age.

Table 3 The evolution of the t-student test values for the trial group

\begin{tabular}{|c|c|c|c|c|c|c|}
\hline $\begin{array}{c}\text { test } \mathrm{t} / \\
\text { Scala }\end{array}$ & VAPS & BFI & QOL & $\begin{array}{c}\text { Food / } \\
\text { Hygiene }\end{array}$ & $\begin{array}{c}\text { Dressed / } \\
\text { undressed }\end{array}$ & $\begin{array}{c}\text { Interaction with the } \\
\text { social environment }\end{array}$ \\
\hline Initial & 0.0302 & 0.0088 & 0.0769 & 0.0113 & 0.0237 & 0.0166 \\
\hline Final & 0.0154 & 0.0029 & 0.0311 & 0.0041 & 0.0187 & 0.0079 \\
\hline Control & 0.0363 & 0.0191 & 0.0356 & 0.0214 & 0.0616 & 0.0292 \\
\hline
\end{tabular}

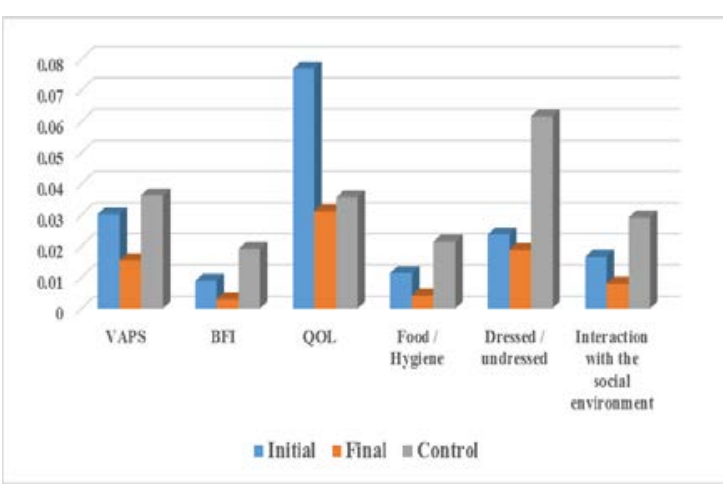

Graph 3 The evolution of the t-student test for the evaluation scales for the trial group 
- For the initial-final moment, the results are statistically significant for the scales VAPS, BIF - for the following segments: Food/Hygiene, Dressed/Undressed, Interaction with the social environment, extremely significant from a statistical point of view for the scale BIF on the whole and totally insignificant for the scale QOL

- For the initial moment - medical check-up, the results are statistically significant for the scales VAPS, QOL, BIF - for the segment Dressed/Undressed, extremely significant from a statistical point of view for the scale BIF on the whole, for the scale BIF for the segment Food/Hygiene, Interaction with the social environment

- For the final moment - check-up, the results are statistically significant for the scales VAPS, BIF, QOL, BIF on the whole, BIF for the segment Food/Hygiene and statistically insignificant for the scale BIF for the segment Dressed/Undressed

Other findings:

- There are no significant modifications according to the location of the lesions of the flexor tendons and of the extensor tendons.

- The recovery treatment influenced the following parameters: pain, functionality and the quality of life.

- The used treatment must be individualized and used progressively.

\section{References}

1. Papilian V. - Anatomia omului (Human anatomy), volume 1, Editura ALL, București, 2006, pages 63-67, 117-123, pages 212-223

2. Sbenghe T. - Recuperarea medicală a sechelelor posttraumatice ale membrelor (The medical recovery of the posttraumatic effects of the limbs), Editura medicală, București, 1981, pages 221-245, 230-231

3. Cooper C. - Fundamentals of hand therapy: clinical reasoning and treatment guidelines for common diagnoses of the upper extremity, Elsevier Mosby, Missoury, 2007, pages 320-346

4. Kisner C., Colby L.A. - Therapeutic exercise, Edition, F.A. Davis Company, Philadelphia, 2007, pages 616-640

5. Iaroslav K. - Fizio-kinetoterapia și recuperarea medicală în afecțiunile aparatului locomotor (The physical kinetic therapy and the medical recovery in the disorders of the locomotor system), Editura Medicală, București, 2007, pages 13-14, 5153

6. Popescu R., Traistariu R. - Recuperarea membrului superior ortezat si protezat (The recovery of the upper limb with orthosis and prosthesis), Editura Medicala Universitara Craiova, 2010, pages 200-212

7. Chiriac M. - Testarea manuală a forței musculare (The manual testing of the muscular force), Editura Universitătii din Oradea, Oradea, 2000, pages 73-105

8. Niculescu C., Cârmaciu R., Voiculescu B., Sălăvăstru C., Niță C., Ciornei C. Anatomia și fiziologia omului-Compendiu 
(Human anatomy and physiologyCompendium), Editura Corint, București, 2009, pages 70-71, 96-104

9. Iacob A. - Aspects about the posttraumatic hand recovery. Sp. Soc. Int. J. Ph. Ed. Sp., 2013, Volume 13, pages 23-27

10. Rusu L., Roșulescu E. - Kinetoterapia în recuperarea afecțiunilor ortopedo-traumatice (Kinetic therapy in the recovery of the orthopaedic traumatic disorders). Editura Universitaria, Craiova, 2007, pages 78-96

11. Savut D.- The role of the proprioceptive neuromuscular facilitation techniques in the rehabilitation of patients with the section of the forearm or hand tendons, Ukrainian Medical Journal of Young Scientists "Khyst", Cernăuți, 2016, page 552.

12. Schöffl V., Heid A., Küpper T. Tendon injuries of the hand, World $\mathrm{J}$. Orthop. 2012, 3(6): pages 62-69

13. Rădulescu A. - Electroterapie (Electrical therapy), Editura Medicală, București, 2014, pages 109-310

14. Zamora E., Crăciun D.-D. - Masaj medical (The medical massage), Editura Risoprint, Cluj- Napoca, 2007, pages 76-78

15. Ionescu A. - Masajul-procedee tehnice, metode, efecte, aplicații în sport (The massage - technical methods, effects and applications in sports), Editura ALL, București, 1994, pages 79-87

16. Diaconu A. - Manual de tehnică a masajului terapeutic (A manual of the therapeutic massage technique), Editura Medicală, București, 2008, pages 386-432

17.Topa I., Stamate T., Popa L. Recuperarea postoperatorie imediată după reinserţia tendonului de flexor profund $\mathrm{cu}$ grefon tendinos din flexorul superficial al degetelor (The immediate postsurgery recovery after the reinsertion of the deep flexor tendon with the tendon graft from the superficial flexor of the fingers), Jurnalul de Chirurgie (Surgery Journal), Iași, 2007, Vol. 3 , nr. 3, pages 253-259.

18. Rădulescu A. - Fizioterapie (Physical therapy), Editura Medicală, București, 2002, pages 18-43

[19] Cinteza D., Munteanu C. - Cercetarea științifică a factorilor naturali terapeutici (The scientific research of the therapeutic natural factors), Editura Balneara, București, 2011, pages 6-20

20. Sbenghe T. - Kinetologie profilactică, terapeutică și de recuperare (Prophylactic, therapeutic and recovery kinetology), Editura Medicală, București, 1987, pages 476-477 